\title{
Interpretation on Social Origin of Southern-American Women's Tragic Fate in A Streetcar Named Desire
}

\author{
Qiang Zhang ${ }^{1}$ \\ ${ }^{1}$ School of Foreign Languages, Shandong Jiaotong University, China \\ Correspondence: Qiang Zhang, School of Foreign Languages, Shandong Jiaotong University, Jinan 250357, \\ Shandong, China. E-mail: 170983040@qq.com
}

Received: May 23, 2014 Accepted: August 11, 2014 Online Published: August 29, 2014

doi:10.5539/ells.v4n3p52 URL: http://dx.doi.org/10.5539/ells.v4n3p52

\begin{abstract}
A Streetcar Named Desire, written by Tennessee Williams, proposes an incisive comment on the way institutions and manner of postwar America imposed restrictions on women's lives, and also demonstrates the embarrassing situation of Southern women in contemporary society. Tennessee Williams spends almost all his life in the South. He pays close attention to the tragic fate of the southern women. This paper mainly consists of three parts. In the first part, the author gives a brief introduction about the plot of the play and the predestined tragic fate of the heroine. The second part mainly discusses the social origin that caused the heroine and southern women's tragedies. Finally the author makes a conclusive statement about the tragic fate of southern women in the play and denounces the male chauvinism and the transition of capitalism in the America.
\end{abstract}

Keywords: tragic fate, personality, Southern women, social origin

\section{Introduction}

A Streetcar Named Desire was first shown on December, 1947 at the Ethel Barrymore Theater; it had left a striking impression on the audience at that time. A Streetcar Named Desire had been displayed for 855 times and became the first play which wins the Pulitzer Prize, the New York Drama Critics' Awards, and the Donaldson Award. As A Streetcar Named Desire first was put on in New York, it had astonished all the audiences and aroused a lot of people's dispute in many respects: sex scandal, sex with men, rape, insanity and other things that are not acceptable by ordinary people. One critic called it the outcome of an "almost desperately morbid turn of mind". Its influence at that moment was particularly great, for it is actually unique since it is a stage piece which is both individual and social and entirely an outcome of our life. In A Theater Divided (1967), Martin Gottfried would regarded it with Death of a Salesman as the most important postwar masterpieces in America; Miller had a remark about the play "a work as important as any other ever written for the American stage" (Note 1).

The play A Streetcar Named Desire depicts the degeneration of a Southern beauty whose name is Blanche Dubois. Blanche, who was once a teacher, arrived at New Orleans and look for shelter to her sister Stella. Blanche is scornful of her sister's living environment. Blanche's insolence aroused the immediate hatred of her sister's husband named Stanley Kowalski. Stella left her patrician family to search for the sexual satisfaction gained from Stanley, and even got pregnant with his child. At poker's night, Blanche unconsciously annoyed Stanley. Stanley casted the radio out of the window and also hit his lover Stella hard. However, Stella came back to Stanley and hugged him with passion as he cried and asked for her forgiveness. The next morning, Blanche attempted to persuade Stella to stop her relation with Stanley. But Stanley happened to hear their conversation. He started to make an investigation on Blanche and knew her notorious past. And this had made Blanche depressed. When Blanche's relationship with Mitch was progressing, Stanley informed her notorious past to Mitch and Stella. Mitch decided not to forgive Blanche and finally left her. Blanche was mentally collapsed. At that time, Stanley committed criminal assault to her and even sent her into bedlam.

This play focuses on the tragedy of the heroine Blanche's emotional life through which Williams depicts the adversity of Southern women during the transition period between modern time and plantation period. Williams also shows his sympathy for them. Blanche finally became mad, and went into a world that she made by herself, the author intend to explore the tragic life of the heroine and southern women and show William's perspectives of tragic fate in his well-known play. 


\section{Interpretation on Social Origin which Caused Southern Women's Tragic Fate}

In the 20th century, the capitalism in America had led to the declination of the Southern plantation-economy society and the prosperous industrial society in northern America. The blossom of northern industry had given a profound and extensive influence on all respects of the modern society, particularly on the mode of life of people in South America; with the industrialism in the north penetrated promptly and gradually into the life of the people in the south, the plantation economic system began to decline and breakdown. There action on culture of the transition period in the society was the collision between the old plantation culture in the South and the new northern industrial culture. The declining process of Southern culture is inevitable. The northern modern culture has destroyed the moral standards and romance of Southern culture to a great extent. In the new industrial society, people often chase after success and economic profits in the fierce competition. Materialism is an obvious characteristic in the life of Americans.

The Southern women who were grown up in the atmosphere of Southern plantation culture might have different options. Some women may adapt to the modern culture and is characterized by it; some women could not comply with the rude and different reality and absorbed in the memories of the old Southern culture. They attempt to apply their illusion of their past experience to get to know about the society and make them known in the society. In their mind, all the old things in their memories of the wonderful Southern culture are beautiful and perfect. Nevertheless, during their fight against the new northern culture, they always lose themselves and end up in tragedy.

In the meantime, around the 1930s, the conventional ethics of Victorian age and morality of sex were prevailing in the American society. It emphasizes on refraining women's desire and be devoted to family. Women have to stay inside home and wait upon their husbands and children. To a degree, the ethics of Victorian age has deprived Southern women of their freedom of thought and left them in a dilemma.

\subsection{The Heroine's Cultural Travel}

Blanche was the outcome of the old southern economy of plantation. She took over the standard behavior in the old South culture from her forefathers. However, the cultural possession she held was harmful to her indirectly. As a puritan, Blanche was unable to forgive her husband's homosexual relationship with others and this had caused his suicide indirectly. Furthermore, Blanche inherits her ancestors' hypocrisy and obscurity over sex. Their "epic fornications" (p. 1834) had given rise to the poverty of the young generation and the missing of Belle Reve. Such being the case, Blanche began to degenerate either due to "panic" leading her to "hunting for protection". Because of her bad reputation, Blanche was expelled out of her hometown; she became a sufferer of Puritanism under which she was brought up. Because Blanche was not just a withered remnant of Southern gentility, she was intently avoiding a world which she couldn't command and had done something terrible to her. She had stuck around during a long time of deaths in her family; every death gradually depraved her of strength and put her prospect into loneliness. Blanche's marriage with a charming boy who anticipated her for spiritual safety was destined from the very beginning; even though she had been a super girl, she couldn't have rescued it.

In order to survive by instinct, Blanche went to Stella's home in New Orleans. Her sole aim was to seek a new life for herself in a different place. Nevertheless, New Orleans was not the perfect place she was hoping for. The Elysian Field was a discomforting, awful place featured by noisy environment, filled with the hoarse sounds of the street venders selling tamales; the continuous rhythms of the honky-tonk "blue piano" the human sounds of brawling and of breathless hysterical laughter. Blanche came to the brutal environment which characterizes the law of the jungle. Kazan wrote in his rehearsal notebooks:"Blanche come into a house where some is going to murder her..." (Note 2). Williams ever depicted the episodic construction of the play in this way, to keep it "on the tracks in those dangerous, fast curves it made here and there" (Note 3).

In a sense, Blanche and Stanley were fighting for Stella and Mitch-all of them would like to pull them beyond the reach of the other. However their conflict was more fundamental and was running through the entire plot. Actually, they represented two inconsistent forces-manners and manhood. Blanche was the representative of the Old South's intelligent romantics and commitment to appearances. Stanley stood for the New South's cruel chase after prosperity and financial realism. Blanche was once the holder of an estate inherited from her father and a highly educated woman; while men like Stanley, Mitch and Steve were workers and they knew nothing but alcohol, women and fight. Robert Bray regarded this transfer of papers blending with bloodiness as a crucial conceptualization in the development of the institution of society from the old South, loaded with its past, which was stood for by Blanche, to the postwar era and urbanized and industrialized society in which Stanley's hierarchy had showed influence.

In the face of a surprised guest, Stanley asked the affairs in his stride. His utterance amounted to nothing more 
than joyous vulgarity. His self-righteous exchange with Blanche indicated him to be callous-he scarcely allowed Blanche break in when he evaluated her beauty quickly; as Blanche passes the pokers, she greeted in a polite way: "Please don't get up." Stanley broke her up: "Nobody's going to get up, so don't be worried" (p. 1836); the fact that Stanley coarsely took all of Blanche's possessions out of her luggage demonstrates that his trampling on the degenerating old South culture which Blanche was standing for. At the poker's night, Blanche turned on the radio and started dancing with Mitch. Stanley stood up, rushing to the radio, and casted it out of the window. Stella shouted at Stanley and was hit by him; Stanley also defied Blanche's in this way: "You come here and sprinkle the place with powder and spray and cover the light bulb with the paper lantern, and to and behold the place has turned into Egypt and you are the queen of the Nile! Sitting on your throne and swilling down my liquor!" (p. 1872). The criminal assault in Scene Ten was a symbol of the ultimate extermination of the old South's elegant illusion world by the brutal but vivacious present. Blanche's cultural benefit was repulsed in each place and she was in a gloomy status which was unrecognized by others. She had no proper place to live and no outlet to abreact her sufferings; she could wait for nothing but the ultimate tragedy in the end.

Blanche' tragedy was either the outcome of the vicious system - the feudal regime of the old South, and she was also the sufferer of the other system: the capitalism of the regenerated unification. She was living in an era in which the conventional moral force was mighty. The moral standards of pilgrims indicated autarchy in every respect of life, which had a deep influence on Blanche's later life.

Blanche remains prisoner to the traditional notions about the women of the old cavalier South: economic dependence was the order of the day, and so women like Blanche were ill-equipped to survive in a changing world by any means except physical attractiveness. Blanche attempts to use her fading good looks to win the hand of a charming suitor. ...Blanche must keep a proper balance, being 'gay' enough to entertain and entice the gentlemen caller without being so sexually forward as to turn him away. Affecting charm and manners, she pathetically tries to keep alive a way of life that has been lost. (Note 4)

With the declination of the manorial economy, she still attempted to adapt to the new but ruthless society by her patrician manner. People did not show any sympathy to Blanche's experiences; instead, they considered her as another kind of person of different culture. She was in need of the concern of others, but finally running into loneliness; she wanted affection from gentlemen, but only being conceived by the actuality. She entrusted wishes to her fascination and manners to make her dreams come true. Nevertheless, the society did not give her opportunities, but only transforming her, controlling her, and ultimately leading to her destruction. Kazan once said: "The crude forces of violence, insensibility and vulgarity crushed the representative of light and culture" (Note 5).

\subsection{Southern Women in Dilemma}

In the autumn of 1937, Williams Tennessee went to the University of Iowa. His life in Iowa was a very important experience in William's composing career: it made him to realize himself as the Southern playwright. It provided him his first systematic revelation to the theory of drama and theatrical composition. Identified as a student from south at Iowa, and entered in the current localism, Williams set the background of his play in the South. Inevitably, Williams created a kind emotion for his birthplace, a feeling that can be called sympathy. In his childhood, he spent an unforgettable time with his relatives in a little town near Mississippi. When they moved to the north, it was a miserable experience for Williams. He and his sister could not give up their past golden life in their hometown. Thus he expressed great sympathy for the Southern women during the transition period of the society.

Tennessee seems to write a mournful poem for the South in his works and demonstrates an attachment emotion to Southern women. He has depicted a group of delicate, strained Southern women in his renowned play. Those women are strangers of northern society, incapable and pervert persons and etc. They all attempt to earn their living in the society, but none of them are successful. The dominant industrialized culture has left those women to struggle diligently but without any achievement. Many of these women are quite similar with the women of Victorian age: they are likely to inherit the Victorian culture which demanded that a woman should be stay at home to be a housewife but not a breadwinner. They are living in an illusion and are incapable of adapting to an intense industrialized society without any humanity. Stella once has made her case to her husband Stanley:

She is. She was. You didn't know Blanche as a girl. Nobody, nobody was tender and trust as she was. But people like you abused her, and forced her to change. (p. 1865)

This was a world of male chauvinism; Blanche is just one symbol of southern women in the industrialized northern society. Blanche's miserable experience exposes the pathetic reality that southern women are oppressed in a society of male chauvinism. A Streetcar Named Desire reveals and criticizes the malformation and 
ruthlessness in the American society, demonstrating an incisive critique of the manner the systems and attitudes of postwar America put limitations on southern women's lives under the transition period from the old south to the new south. It also reflects the dilemma of Southern women in the highly industrialized and modern society. In this play, nearly all the women performing on the stage share the common features on the above question, such as Blanche, Stella, and Eunice, a black women, the streetwalker, etc.

Blanche and her sister were both brought up in an aristocratic family and share the same cultural background. They got common education and they were the southern women under considerable culture. Nevertheless, both of them were born with tragic feature in their emotional life. Blanche once said:"The blind are leading the blind!" (p. 1835), they were leading life that does not have future after the declination of the South plantation economy. Blanche once experienced the death of her parents and other family members and the loss of Belle Reve. She was a distinct brand at that time, Blanche conflicted fiercely with the social reality that is unfamiliar to her, and finally she was mentally collapsed and was delivered into a lunatic asylum; her sister Stella was allured by Stanley's power and violence. She was glad to leave behind her the self-glorifications of her background to get the sexual satisfaction from Stanley in return whom she had married. She was hoping to be a housewife of her husband and waiting for the "bag" he brings every day. To some extent, Stella had turned against her aristocratic lineage and married Stanley who was in the lower-class; the inferior life had changed her and she was completely degenerated into a worshipper of Stanley and she always had pride in his husband's violence and strength. Stanley's cruel behaviors increased Stella's affection for him. As Stella told Blanche that her husband broke all the light bulbs with her shoes when they were taking honeymoon, Blanche got terrified: "He did-what?" But Stella told Blanche she felt that scene very exciting, "I was-sort of-thrilled by it" (p.1843). She was muddle headed with sexual satisfaction, "But there are things that happen between a man and a woman in the dark - that sort of make everything else seem-unimportant" (p. 1845). After the poker's night, while Stella was beaten by Stanley and got pregnant, she still went for a long way to have sex with Stanley. Stella, the same as other low-class wives, repeated the boring life day by day and lived an unenlightened and satisfactory life in her husband's sexual world by not realizing the intrinsic meaning of it.

The final ending of the two sisters are completely different: one is abandoned by the society and finally delivered into the lunatic asylum; another conceded with the fact and is accommodated. However, regardless of the fact whether Blanche stays at plantation period or Stella is in northern modern times, they share something in common: as the southern plantation women, they lost themselves in society and they are vulnerable, aimless, and have a hollow spirit. The modern society changes and alienates them. They are very clear about the strengths of the atmosphere and their small and weak, and in the end Stella still pursues the accustomed life with her husband Stanley and abandons her sister.

Eunice lives in the upstairs; she is the landlady and Stella's friend. She and Steve is the symbol of the lower-lass, Eunice's home can be regarded as a perfect shelter for Stella and Blanche. When the two sisters are fighting with Stanley, they would escape from him by going upstairs. While this kind of escape is of no use and temporary, they are waiting for Stanley's the begging for pardon at anytime. So their compromise is a kind of token but not really useful. When the two women went upstairs one evening, Stanley shouted in the downstairs: "STELL-LAHHHH!" The voice penetrated into the night just as a hurting wolf crying for the return of his spouse. In the end, Stella, in disarray, walked out of the room and down to Stanley. Stanley fell to his knees, gently fondle her face and belly, and then hold her up and brought her into their room. From this kind of relationship, we can easily find that Stella was reluctant to leave her beloved Stanley and what she was doing is only to find a pretext for her admiration. The Southern women like Stella or Eunice relied greatly on their husbands both in material and emotion, despite the fact that those men always got drunken, violent and like gambling. As a matter of fact, these kinds of families often perform like this in an ironical way: tolerance-quarrel-reconciliation-quarrel again...violence and tolerance compromises.

Although Stella concerned her sister from her inner heart, she unintentionally became the accomplice of Stanley's abuse on her sister Blanche. In this play, Blanche once told her sister that Stanley had committed criminal assault to her. However, Stella said: "I couldn't believe her story and go on living with Stanley." When Eunice heard about that, she comforted Stella by saying this: "Don't even believe it. Life has to go on. No matter what happens, you've got to keep on going." (p. 1873) Eunice played the role as a mediator, but she had disguised the reality and misled Stella to avoid her duty and denied to accept the reality of Stanley' crime. Stella went on living with the abnormal killer. However Blanche was sent into the deep hell and became the victim of incest and rape. Stella and Eunice considered Blanche as a crazy woman and finally sent her together with Stanley into a lunatic asylum. Stanley is an abnormal murderer just like an animal; while Stella and Eunice were the women who have lost their conscience, help and instigate the animal-like murderer. They had together 
compelled Blanche to come to a dead end.

Thomas Porter focuses on William's handling of the dying out of the old South through his character study of Blanche, who is both the alien "intruder" upon an "established way of life" as well as the traditional "heroine of romance." This tension is further exacerbated by the playwright's ambivalence about sex, which, to Porter's way of thinking, helps account for the play's final lack of resolution, with William's Southerner...caught between two worlds, one gone with the wind, the other barely worth having. (Note 6)

Blanche took the streetcar named desire to get cross the road. People on the road are ruthless and snobbish. Blanche once tried to seek a livelihood, but people pulled her down the streetcar. It is the ruthless people who have sentenced her into emotional death. Blanche was unfortunately living in a transition period of the America. It is the old society's hypocrisy and new times' cruelty that killed her prospect and finally led to her tragedy.

\section{Conclusion}

Correctly, the theme of sex and desire is common in William's works. But with its revelation and dramatization of sexual misconduct, its delineation of a horrifying descent into madness, its portrayal of women driven and even controlled by desire, A Streetcar Named Desire, in fact, offered themes that couldn't be accommodated to any standard Hollywood schema.

Williams has been deeply affected by his own ambiguous nature and his Southern background. Williams has entrusted himself into his auto biographical works $A$ Streetcar Named Desire. He has ever declared in public that he is Blanche Dubois. In this play, Blanche is a character who has got access to the virtual world of the American people. By the tragic fate of Blanche and her disappointed fight for love and new life, Williams revealed the dilemma the southern women was facing with and expressed tremendous sympathy for them. In this play, Williams also described a world which is governed by men, in this world the females are perceived as a group that can be served as men's contentment in sex and self-approval of their domination in current society. Furthermore, the notions of society restrict the ideal women for marriage. Blanche was regarded as a woman who was immoral and was not allowed to get married.

There is no purpose in A Streetcar Named Desire. It solves no problems; it arrives no general moral conclusions. It is the rueful character portrait of Blanche Dubois and other southern women. Blanche is one of the most tragic figures in the modern theater. There is no grandeur in the remnant we are now permitted to see. There is nothing, in fact, expect desperate affection, terror, and weak and futile rage in the play. With his characteristic dramaturgy, verbal and visual language, and thematic preoccupations, Williams reveals the tragic fate of Blanche by describing her spiritual collapse, expresses the author's sympathy for the misfortunes of southern women in the transition period of the society, and then brings to the readers' attention to the fate and status of southern women in Western society.

\section{References}

Adler, T. P. (1990). "A Streetcar Named Desire": The moth and the Lantern. Boston: Twayne Publishers (Twayne's Masterwork Studies, no. 47).

Atkinson, B. (1996). Second Chance, Summer and Smoke Put On in Sheridan Square. The Critical Response to Tennessee Williams. Westport, Connecticut: Greenwood Press.

Bigsby, C. W. E. (1992). Modern American Drama, 1945-1990. New York: Cambridge Univ. Press.

Boek, H., \& Albert W. (Eds.). (1981). Essays on Contemporary American Drama. Munchen: Max Hueber Verlag.

Corrigan, M. A. (1976). Realism and Theatricalism Desire in a Streetcar Named Desire. Modern Drama, 19.

Elia, K. (1963). Notebook for A Streetcar Named Desire. In T. Cole \& H. C. Chinoy (Eds.), Directors on Directing (Indianapolis: Bobbs-Merri11).

Fleche, A. (1995). The Space of Madness and Desire: Tennessee Williams and Streetcar. Modern Drama, 38.

Hirsch, F (1979). A Portrait of the Artist: The Plays of Tennessee Williams. Port Washington, NY: Associated Faculty Press.

Kolin, P. C. (Ed.). (1993). Confronting Tennessee William's “A Streetcar Named Desire”. Essays in Critical Pluralism. Westport, CT: Greenwood Press.

Poter, T. E. (1969). The Passing of the Old South: A Streetcar Named Desire. Myth and Modern American Drama. Detroit: Wayne State University Press. 
Roudane, M. C. (2000). Tennessee Williams. Shanghai: Shanghai Foreign LanguageEducation Press.

Spoto, D. (1985). The Kindness of Strangers: The Life of Tennessee Williams. Boston: Little Brown.

Williams, T. (1947). A Streetcar Named Desire. New York: Two Rivers Enterprises, Inc.

Williams, T. (1975). Memoirs. Garden City, New York: Double Day.

Williams, T. (1978). Where I live: Selected Essays. New York: New Directions.

Wilson, G. B. (1973). Three Hundred Years of American Drama and Theater.

Xu, J. C. (2012). Analysis on Symbolic Meaning of Blanche. English Language and Literature Studies, 2(4), 77-82. http://dx.doi.org/10.5539/ells.v2n4p77

Yacowar, M. (1977). Tennessee Williams and Films. New York: Ungar.

\section{Notes}

Note 1. Martin Gottfried, A Theater Divided: The Postwar American Stage (Boston: Little, Brown, 1967); Jordon Y Miller, ed., Twentieth century Interpretations of "A Streetcar Named Desire" (Englewood Cliffs, N. J.: Prentice-Hall, 1971), p.9.

Note 2. Elia Kazan, "Notebook for A Streetcar Named Desire," Toby Cole and Helen Crich Chinoy (eds.), Directors on Directing (Indianapolis: Bobbs-Merrill, 1963), p.366.

Note 3. Tennessee Williams, Where I Live: Selected Essays, ed. Christine R. Day and Bob Woods (New York: new Directions, 1978), p.93. Hereafter cited by Essays and page number within the text.

Note 4. Thomas P. Adler, "A Streetcar Named Desire: the Moth and the Lantern" (Boston: Publisher, 1990), p.40.

Note 5. Thomas E. Porter, Myth and Modern American Drama (Detroit: Wayne State University Press, 1969), p.176.

Note 6. Chinoy (ed.), Directors on Directing (Indianapolis: Bobbs-Merrill, 1963), pp.364-366.

\section{Copyrights}

Copyright for this articleis retained by the author(s), with first publication rights granted to the journal.

This is an open-access article distributed under the terms and conditions of the CreativeCommons Attribution license (http://creativecommons.org/licenses/by/3.0/). 